\title{
Development of Microsatellite Markers from Crape Myrtle (Lagerstroemia L.)
}

Xinwang Wang ${ }^{1}$

Texas AgriLife Research and Extension Center, Texas A\&M University

System, 17360 Coit Road, Dallas, TX 75252

Deborah Dean, Phillip Wadl, and Denita Hadziabdic

Department of Entomology and Pathology, University of Tennessee, Knoxville, TN 37996

\section{Brian Scheffler}

USDA-ARS-CGRU MSA Genomics Laboratory, 141 Experiment Station Road, Stoneville, MS 38776

\section{Timothy Rinehart}

USDA-ARS Thad Cochran Southern Horticultural Laboratory, 810 Highway

26 West, Poplarville, MS 39470

\section{Raul Cabrera}

Texas AgriLife Research and Extension Center, Texas A\&M University System, Dallas, TX 75252

\section{Robert Trigiano}

Department of Entomology and Pathology, University of Tennessee, Knoxville, TN 37996

Additional index words. cross-species transfer, ornamental plant breeding, simple sequence repeats

\begin{abstract}
Lagerstroemia L. (crape myrtle) is an economically important woody plant genus with several deciduous flowering ornamental species. A wide range of flower colors, long flowering periods, growth habits ranging from miniature to tree sizes, and exfoliating bark characteristics provide horticulturists and nursery growers with a great deal of interest in the breeding and genetics of this genus. We report microsatellite marker development from a GT-enriched genomic library of the interspecific hybrid 'Natchez' ( $L$. indica L. $\times$ L. fauriei Koehne). Twelve of 43 novel microsatellite loci were characterized on a collection of 33 Lagerstroemia cultivars and accessions. Four to eight alleles per locus (mean $=\mathbf{5 . 6}$ alleles) were detected. Allelic richness ranged from 3.9 to 7.2 with a mean of 5.3. The level of polymorphism detected (average gene diversity of 0.68 ) indicates moderately high genetic diversity within the selections of crape myrtle cultivars and accessions. The examined markers also exhibited high cross-species transferability to L. fauriei, L. limii Merr., and L. subcostata Koehne.
\end{abstract}

The genus Lagerstroemia L. contains shrubs or trees that are primarily native to tropical regions of southeastern Asia and Indo-Malaysia (Furtado and Srisuko, 1969),

Received for publication 23 Feb. 2010. Accepted for publication 10 Mar. 2010.

Xinwang Wang, Deborah Dean, and Phillip Wadl contributed equally to this work.

This work was performed under the new faculty financial support by Texas AgriLife Research and Extension Center at Dallas and the U.S. Department of Agriculture Grant \# 58-6404-7-213.

Mention of trade names or commercial products in this article is solely for the purpose of providing specific information and does not imply recommendation or endorsement by Texas AgriLife Research and Extension Center, Texas A\&M System, University of Tennessee, or the U.S. Department of Agriculture.

${ }^{1}$ To whom reprint requests should be addressed; e-mail xw-wang@tamu.edu. age comparison, and interspecific hybrid analysis (Pooler, 2003; Pounders et al., 2007). We report the development of microsatellites from crape myrtle 'Natchez' (L. indica $\times L$. fauriei) using a biotin enrichment protocol (Wang et al., 2007) and test their amplification in 33 L. indica cultivars (including interspecific hybrids) and accessions. These polymorphic markers were also tested for cross-species amplification in three other Lagerstroemia species ( $L$. fauriei, L. limii, and $L$. subcostata). These microsatellites will be useful in assessing genetic diversity of cultivars and hybrids of $L$. indica and L. fauriei and other Lagerstroemia species.

Microsatellite sequences were obtained from a genomic library of crape myrtle 'Natchez' enriched for (GT) $)_{n}$ using biotin hybridization (Wang et al., 2007) with minor modifications. Genomic DNA of 'Natchez' (and all samples analyzed) was isolated using the E.Z.N.A. ${ }^{\mathrm{TM}}$ Plant DNA Kit (Omega BioTek, Norcross, GA) following the manufacturer's instructions and digested with Alu I and Hae III, and 300 to $800 \mathrm{bp}$ blunt-end fragments were ligated to SNX linker adaptors (Hamilton et al., 1999) and then polymerase chain reaction (PCR)-amplified using SNX forward primer. The PCR products were column-purified with a QIAquick PCR purification Kit (QIAGEN, Valencia, CA) and hybridized to (GT) 12 biotinylated oligonucleotides to enrich fragments containing $(\mathrm{GT})_{\mathrm{n}}$ microsatellite sequences. Streptavidin-coated paramagnetic particles (Promega, Madison, WI) were then bound to genomic DNA (fragments)-biotin labeled oligonucleotide hybrids. After consecutive wash steps with sodium chloride/sodium citrate (SSC) and sodium dodecyl sulphate (SDS), microsatellite repeat-enriched fragments (single-stranded) were eluted and made doublestranded in a PCR using SNX forward primer. The double-stranded fragments were purified with the QIAquick PCR purification kit and ligated to $E c o R V$-cut pBluescript SK (+) vector (Stratagene, Hanover, MD).

The recombinant DNA was transformed into One Shot ${ }^{\circledR}$ Top 10 chemically competent Escherichia coli cells (Invitrogen, Cedar Creek, TX). Transformed cells were spread onto petri plates containing LB medium solidified with agar and supplemented with $100 \mu \mathrm{g} \cdot \mathrm{mL}^{-1}$ ampicillin plus indicator IPTG and X-Gal and incubated at $37^{\circ} \mathrm{C}$ overnight. Individual white colonies were transferred using autoclaved toothpicks into 96-well storage plate containing LB freezing medium (Sambrook et al., 1989) with $100 \mu \mathrm{g} \cdot \mathrm{mL}^{-1}$ ampicillin and incubated at $37{ }^{\circ} \mathrm{C}$ overnight (without shaking).

To detect putative microsatellites from cloned DNA fragments, colony PCR was performed as described previously (Wang et al., 2007) with minor modification. Briefly, $10-\mu \mathrm{L}$ PCR volume consisted of $1 \times$ GoTaq green reaction buffer (Promega), $2.5 \mathrm{~mm}$ $\mathrm{MgCl}_{2}, 0.2 \mathrm{~mm}$ dNTPs, $0.25 \mu \mathrm{M} \mathrm{T}$ primer, $0.25 \mu \mathrm{M} \mathrm{T}_{7}$ primer, $0.25 \mu \mathrm{M}(\mathrm{GT})_{12}$ oligo, 0.2 U GoTaq DNA Polymerase (Promega), and sterile water. The PCR amplifications were performed on a MyCycler Thermal Cycler 
(BIO-RAD, Foster City, CA) using the following conditions: one cycle at $95^{\circ} \mathrm{C}$ for $3 \mathrm{~min}, 35$ cycles at $95^{\circ} \mathrm{C}$ for $1 \mathrm{~min}, 50{ }^{\circ} \mathrm{C}$ for $1 \mathrm{~min}, 72$ ${ }^{\circ} \mathrm{C}$ for $1 \mathrm{~min}$, and one cycle at $72{ }^{\circ} \mathrm{C}$ for $1 \mathrm{~min}$. PCR products were separated on $2 \%$ agarose gels and colonies were considered positive for an inserted microsatellite motif if a smear was present on the gel (Wang et al., 2007).

Ninety-six positive colonies were duplicated into a new 96-well plate containing 200 $\mu \mathrm{L}$ LB freezing medium and $100 \mu \mathrm{g} \cdot \mathrm{mL}^{-1}$ ampicillin (Sambrook et al., 1989). Plasmid DNA of the colonies was isolated using the PureLink $^{\text {TM }} 96$ HQ Mini Plasmid DNA Purification Kit (Invitrogen) following the manufacturer's instructions and sequenced with pJET sequencing primers following the standard BigDye 3.1 sequencing protocol. Products were resolved on an ABI 3130XL genetic analysis system (Amersham, Foster City, CA).

Of the 96 positive colonies sequenced, 87 (91\%) contained microsatellite repeats and 44 sequences either contained short repeats (less than five) or did not have sufficient flanking region to design optimum primers. These sequences and any duplicated sequences were discarded from the study. Consequently, 43 microsatellite primer pairs were designed using Primers3 (Rozen and Skaletsky, 2000) and synthesized by Integrated DNA Technologies.

Designed primer pairs were tested for polymorphisms using 30 cultivars (including interspecific hybrids) and three accessions from L. indica species ['Apalachee', 'Arapaho', 'Arkansas Red', 'Byers Standard Red', 'Carolina Beauty', 'Centennial Spirit', 'Gamad I' (Cherry Dazzle $\left.{ }^{\circledR}\right)$, 'Cheyenne', 'Christiana', 'Dallas Red', 'Houston', 'Moned' (Chica
$\left.\operatorname{Red}^{\circledR}\right)$, 'Monia' (Majestic Orchid ${ }^{\circledR}$ ), 'Musgokee', Natchez, 'New Orleans', 'Orlando', 'Ozark Spring', 'Peppermint Lace', 'Monhid' $\left(\right.$ Petite Orchid $\left.{ }^{\circledR}\right)$, 'Piroska', 'Queen's Lace', 'Whit VII' (Siren Red ${ }^{\circledR}$ ), 'Whit V' (Tightwad $\left.^{\circledR}\right)$, 'Tonto', 'Twilight', 'Velma's Royal Delight', 'Weeping Red', 'Wichita', 'William Toovey', NA63872, NA67620, and NA69850]. The polymorphic markers were also tested for cross-species amplification in $L$. fauriei ('Kiowa'), L. limii, and L. subcostata (NA40181). Microsatellite amplification was performed using the following PCR conditions: $10-\mu \mathrm{L}$ reaction containing $1 \mathrm{ng}$ genomic DNA, $1 \times$ GoTaq green reaction buffer (Promega), $2.5 \mathrm{~mm} \mathrm{MgCl}_{2}, 0.2 \mathrm{~mm}$ dNTPs, $0.25 \mu \mathrm{M}$ of each primer, $0.2 \mathrm{U}$ GoTaq DNA Polymerase (Promega), and sterile water. The PCR profile was conducted on a MyCycler Thermal Cycler (BIO-RAD) consisting of $3 \mathrm{~min}$ at $95^{\circ} \mathrm{C}, 35$ cycles of $95^{\circ} \mathrm{C}$ for $40 \mathrm{~s}, 55^{\circ} \mathrm{C}$ for $40 \mathrm{~s}, 72^{\circ} \mathrm{C}$ for $30 \mathrm{~s}$, and a final extension of $72{ }^{\circ} \mathrm{C}$ for 4 min.

Twelve of the 43 microsatellites primer pairs successfully amplified genomic DNA and showed polymorphisms on 3\% Metaphor ${ }^{\circledR}$ agarose gels (Lonza, Rockland, ME). These PCR products were also analyzed on a QIAxcel Capillary Electrophoresis System (QIAGEN) using a 25-bp DNA step ladder to allow consistent allele size calling for all loci and samples tested. All loci were polymorphic and produced clear and reproducible alleles within the expected size range (Table 1). Linkage disequilibrium and deviations from the Hardy-Weinberg equilibrium (HWE) for 12 loci were calculated using GENEPOP Version 4.0.10 (Rousset, 2008). All loci showed significant deviations from HWE.
These deviations probably resulted from the small population size and the absence of nonrandom mating resulting from the selection process used to sample the cultivars tested in this study. Linkage disequilibrium was not significant $(P<0.05)$ for all pairwise comparisons of the 12 loci tested. The allele numbers per locus $(A)$ and allelic richness $\left(R_{S}\right)(\mathrm{El}$ Mousadik and Petit, 1996) were computed using Fstat 2.9.3.2 software (Goudet, 2001). The number of alleles per locus detected ranged from four to eight with an average of 5.58. Allelic richness for all samples tested ranged from 3.94 to 7.17 with an average of 5.25 . Observed heterozygosity (gene diversity) ranged from 0.54 to 0.75 with a mean of 0.68 and expected heterozygosity ranged from 0.06 to 1.00 with an average of 0.43 . This moderately high genetic diversity indicated that there is genetic variation in the limited genetic germplasm of crape myrtle breeding programs.

Results of this study indicate that the 12 microsatellite loci characterized here have potential in genetic diversity analyses across the genus Lagerstroemia. The 30 cultivars and three accessions from $L$. indica (including 10 of their interspecific hybrids) and another three Lagerstroemia species (L. fauriei, $L$. limii, and L. subcostata) used in this study represent a broad spectrum of ornamental and horticultural traits found in crape myrtle and the genetic diversity is reflected in the polymorphic content of some loci (for example, LID020, LID031, LID032, and LID038). These loci will be useful for genetic linkage mapping, population and genetic studies as well as for future crape myrtle breeding programs. Cross-species amplification results indicate that the L. indica microsatellite markers

Table 1. Characterization of 12 microsatellite loci isolated from crape myrtle 'Natchez' (Lagerstroemia indica $\times$ L. fauriei) based on 33 Lagerstroemia cultivars and accessions. ${ }^{2}$

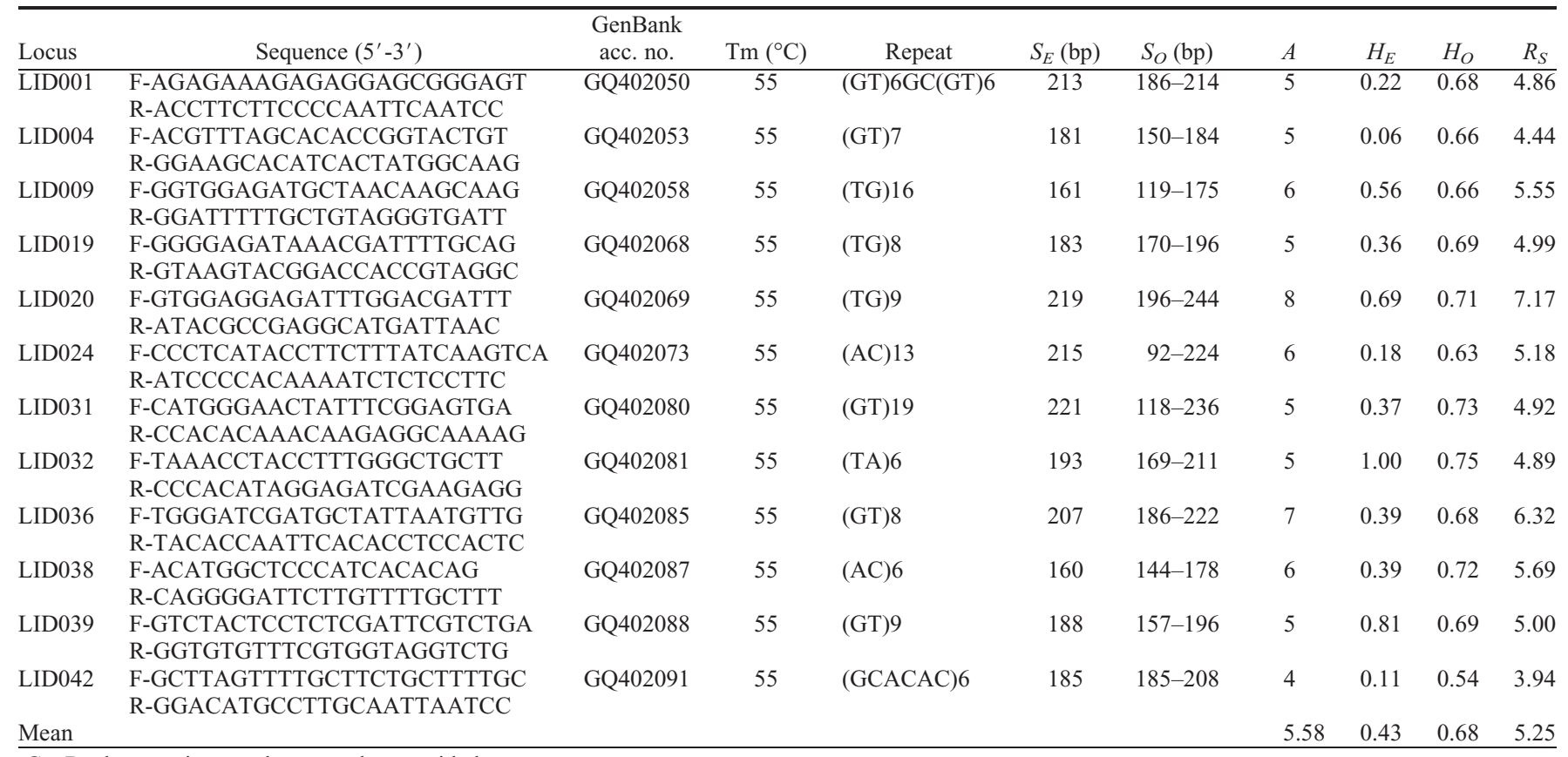

${ }^{2}$ GenBank accession numbers are also provided.

$\mathrm{F}=$ forward primer sequence; $\mathrm{R}=$ reverse primer sequence; $\mathrm{Tm}=$ annealing temperature; $\mathrm{S}_{E}=$ expected allele size; $\mathrm{S}_{O}=$ observed allele size; He $=$ expected heterozygosity; $H o=$ observed heterozygosity; $A=$ allele numbers per locus; $R s=$ allelic richness. 
are likely to be informative in other related Lagerstroemia species such as L. fauriei, $L$. limii, and L. subcostata.

\section{Literature Cited}

Cabrera, R.I. 2004. Evaluating and promoting the cosmopolitan and multipurpose Lagerstroemia. Acta Hort. 630:177-184.

El Mousadik, A. and R.J. Petit. 1996. High level of genetic differentiation for allelic richness among populations of the argan tree [Argania spinosa (L.) Skeels] endemic to Morocco. Theor. Appl. Genet. 92:832-839.

Furtado, C.X. and M. Srisuko. 1969. A revision of Lagerstroemia indica L. (Lythraceae). Garden Bull. (Singapore) 24:185-334.

Goudet, J. 2001. FSTAT, a program to estimate and test gene diversities and fixation indices (ver- sion 2.9.3). 10 Feb. 2010.<http://www2.unil.ch/ popgen/softwares/fstat.htm>.

Hamilton, M.B., E.L. Pincus, A. Di Fiore, and R.C. Fleischer. 1999. Universal linker and ligation procedures for construction of genomic DNA libraries enriched for microsatellites. Biotechniques 27:500-507.

Pooler, M. 2003. Molecular genetic diversity among 12 clones of Lagerstroemia fauriei revealed by AFLP and RAPD markers. HortScience 38:256-259.

Pooler, M. 2007. Crapemyrtle, Lagerstroemia indica, p. 439-457. In: Anderson, N.O. (ed.). Flower breeding and genetics. Springer, Dordrecht, The Netherlands.

Pounders, C.T., T. Rinehart, and H. Sakhanokho. 2007. Evaluation of interspecific hybrids between Lagerstroemia indica and L. speciosa. HortScience 42:1317-1322.
Rousset, F. 2008. Genepop'007: A complete reimplementation of the Genepop software for Windows and Linux. Mol. Ecol. Res. 8:103106.

Rozen, S. and H.J. Skaletsky. 2000. Primer3 on the WWW for general users and for biologist proammers, p. 365-386. In: Krawetz, S. and S. Misener (eds.). Bioinformatics methods and protocols: Methods in molecular biology. Humana Press, Totowa, NJ.

Sambrook, J., E.F. Fritsch, and T. Maniatis. 1989. Molecular cloning: A laboratory manual. Cold Spring Harbor Laboratory Press, Cold Spring Harbor, NY.

Wang, X.W., R.N. Trigiano, M.T. Windham, R.E. DeVries, B.E. Scheffler, T.A. Rinehart, and J.M. Spiers. 2007. A simple PCR procedure for discovering microsatellites from small insert libraries. Mol. Ecol. Notes 7:558-561. 